\title{
Research Article \\ Identification of Drug-Related Problems in Hypertension Comorbid Type 2 Diabetes Mellitus Patients at Primary Health Care Center Batununggal District Bandung
}

Vina Septiani ${ }^{1^{*}}$
Pudjiastuti Kartidjo ${ }^{1}$
Alfi Nurul Islamiyah ${ }^{1}$
Abdul Aziz M.S.W. ${ }^{1}$
Iis Rukmawati ${ }^{2}$
1Department of Pharmacy, Universitas
Jenderal Achmad Yani, Cimahi, West
Java, Indonesia
2Pharmacy Unit, Ibrahim Adjie Health
Center, Bandung, West Java, Indonesia
*email:
vina.septiani@lecture.unjani.ac.id
Keywords:
Drug related problems
Hypertension
Type 2 diabetes mellitus

\begin{abstract}
Many factors can increase the risk of hypertension, one of which is diabetes mellitus. The study aims to provide an overview of DrugRelated Problems (DRPs) in patients with hypertension comorbid type 2 diabetes mellitus at Primary Health Care Center Batununggal District Bandung. This research was an observational study with retrospective data collection and descriptive analysis. Data were taken from patient prescriptions January-December 2019 period. The sample inclusion criteria are patients aged 30-75 years, patients diagnosed with hypertension comorbid type 2 diabetes mellitus, and patients treated in January-December 2019. The number of samples that met the inclusion criteria was 268 patients, of which 69 patients $(25.75 \%)$ are male, and 199 patients $(74.25 \%)$ are female. 164 patients $(61.2 \%)$ are aged $60-75$ years old. It is found that 1 case $(0.37 \%)$ has the drugrelated problem of drug overdose and as many as 34 cases $(12.69 \%)$ have potential drug interactions.
\end{abstract}

Received: January $6^{\text {th }}, 2021$

Accepted: July 6 $6^{\text {th }}, 2021$

Published: August 30th, 2021 Institute for Research and Community Services Universitas Muhammadiyah Palangkaraya. This is an Open Access article under the CC-BY-SA License (http://creativecommons.org/licenses/by-sa/4.0/). DOI: https:// doi.org/10.33084/bjop.v4i3.1971

\section{INTRODUCTION}

Patients with hypertension often show evidence of insulin resistance, and up to $75 \%$ of adults with diabetes also have hypertension'. Many factors can increase the risk of hypertension, one of which is diabetes mellitus $(\mathrm{DM})^{2}$. Peripheral artery resistance and body fluid volume increase in DM patients, both of these mechanisms can increase blood pressure? ${ }^{3}$.

Type 2 diabetes mellitus (T2DM) is associated with a high risk of mortality in hypertension patients ${ }^{4}$. Hypertension treatment aims to reduce mortality and morbidity, where drug selection is essential in therapy success 5 . Some references show that the potential for drug-related problems increases in patients with chronic diseases, including $\mathrm{T} 2 \mathrm{DM}^{6,7}$.

Our previous research has found that $\mathrm{T} 2 \mathrm{DM}$ is a common comorbid disease in hypertension patients ${ }^{8}$. However, there is no research on drug-related problems in hypertension with comorbid T2DM patients at Primary Health Care Center at Batununggal District, Bandung. Therefore, researchers are interested in researching drug-related problems in hypertension with comorbid T2DM patients, which has never been done before. This research aimed to find whether there are drug-related problems in hypertension with comorbid T2DM patients, providing information for other health 
professionals to improve patients' service and achieve treatment targets.

\section{MATERIALS AND METHODS}

\section{Materials}

The tool for data collection was a laptop, and the materials used were a prescription sheet of hypertension with comorbid T2DM patients, references, i.e., research journals, and textbook (Pharmacotherapy: A Pathophysiology Approach) ${ }^{9}$. The data for the study was taken from a prescription sheet. Data collected included patient name (initials), gender, age, diagnosis, drugs data (name, dosage strength, dosage form, quantity, and frequency of use). A prescription sheet of hypertension comorbid T2DM patients between January and December 2019 was obtained with a total of 303 samples.

\section{Methods}

The research conducted was an observational study with retrospective data collection and descriptive analysis. The aim was to identify any drug-related problems in hypertension with comorbid T2DM patients at Primary Health Care Center Batununggal District Bandung. The samples taken were adjusted to the inclusion and exclusion criteria that had been set. Inclusion criteria: Patients aged 30-75 years, Patients diagnosed with hypertension with comorbid T2DM, and patients treated in January-December 2019. Exclusion criteria: Patients who were pregnant or breastfeeding and patients with an incomplete prescription. Data that met the inclusion criteria were taken and analyzed quantitatively (number of patients based on gender, age, and diagnosis; data of drug use; percentage of drug-related problems case) and qualitatively (analysis of drug-related problems). This study has received ethical approval from The Health Research Ethics Committee of the Faculty of Medicine of Universitas Jenderal Achmad Yani with reference number 032/UM4.10/2020.

\section{RESULTS AND DISCUSSION}

The research was conducted at Primary Health Care Center at Batununggal District Bandung. Data used in this research were from January to December 2019, with the number of samples obtained as many as 268 met inclusion criteria. The samples used were patients with a diagnose of hypertension with comorbid T2DM according to the inclusion criteria.

Table I showed that from 268 patients, 69 patients $(25.75 \%)$ were male, and 199 patients (74.25\%) were female. These results were in line with the previous research conducted at the same Primary Health Care Center in 2019, in which the most treated patients were female patients. Likewise, the result of Riset Kesehatan Dasar (Riskesdas) 201810, the percentage of hypertension prevalence in female patients was higher than in male patients. The incidence of hypertension is higher in women because in the menopause phase, there is a hormonal imbalance, which is a decrease in the ratio of estrogen and androgen, which causes an increase in the release of renin, which will lead to an increase in blood pressure ${ }^{11}$. Apart from gender, age also affects the incidence of hypertension, the age range 55-90 years has a four times higher risk than those aged 18-54 years ${ }^{12}$.

The patients taken were at least 30 years old because, from previous research ${ }^{8}$, patients admitted to Primary Health Care Center at Batununggal District Bandung were at least 30 years old. In this study, patients aged 6075 years $(61.20 \%)$ had the most hypertension due to increasing age, structural and functional changes that caused the arteries to lose their flexibility. When the flexibility decreases, the blood vessels become stiff; therefore, the blood with each heartbeat is forced through the narrow blood vessels, increasing blood pressure ${ }^{13}$. Factors like gender, smoking, alcohol consumption, overweight, and obesity also were associated with hypertension, diabetes, and dyslipidemia ${ }^{14}$. 
The majority of hypertension with comorbid T2DM patients suffer from other comorbidities. Due to this multi-diagnosis condition, the patient takes a wide range of drugs and increases the risk of drug-related problems ${ }^{15}$. Another comorbidity with the highest percentage in hypertension with comorbid T2DM patients was hyperlipidemia (31.34\%).

Table I. Characteristics of hypertension patients with comorbid T2DM at Primary Health Care Center at Batununggal District Bandung

\begin{tabular}{|c|c|c|}
\hline Parameters & $\begin{array}{c}\text { Number of } \\
\text { Patients }\end{array}$ & $\begin{array}{c}\text { Percentage } \\
(\%)\end{array}$ \\
\hline \multicolumn{3}{|l|}{ Gender } \\
\hline Male & 69 & 25.75 \\
\hline Female & 199 & 74.25 \\
\hline Total & 268 & 100 \\
\hline \multicolumn{3}{|l|}{ Age (year) } \\
\hline $30-44$ & 4 & 1.49 \\
\hline $45-59$ & 100 & 37.31 \\
\hline $60-75$ & 164 & 61.20 \\
\hline Total & 268 & 100 \\
\hline \multicolumn{3}{|l|}{ Diagnose } \\
\hline Hypertension + T2DM & 86 & 32.09 \\
\hline $\begin{array}{l}\text { Hypertension + T2DM + Other } \\
\text { Comorbidities }\end{array}$ & 182 & 67.91 \\
\hline Total & 268 & 100 \\
\hline \multicolumn{3}{|l|}{ Other comorbidities } \\
\hline Hyperlipidemia & 84 & 31.34 \\
\hline Hyperuricemia & 23 & 8.58 \\
\hline $\begin{array}{l}\text { Joint and Connective Tissues } \\
\text { Diseases }\end{array}$ & 51 & 19.03 \\
\hline $\begin{array}{l}\text { Gastrointestinal System } \\
\text { Diseases }\end{array}$ & 22 & 8.21 \\
\hline $\begin{array}{l}\text { Skin and Subcutaneous Tissue } \\
\text { Diseases }\end{array}$ & 13 & 4.85 \\
\hline Respiratory System Diseases & 10 & 3.73 \\
\hline Infectious Diseases & 6 & 2.24 \\
\hline Gastrointestinal Diseases & 5 & 1.87 \\
\hline Circulatory System Diseases & 4 & 1.49 \\
\hline Eye Diseases & 4 & 1.49 \\
\hline $\begin{array}{l}\text { Genitourinary System } \\
\text { Diseases }\end{array}$ & 2 & 0.75 \\
\hline Psychiatric Diseases & 1 & 0.37 \\
\hline $\begin{array}{l}\text { Others (Hemoptysis; Cough; } \\
\text { Other chest pain; Fever, } \\
\text { unspecified; Headache; }\end{array}$ & 20 & 7.46 \\
\hline Localized edema; Obesity; & & \\
\hline $\begin{array}{l}\text { Superficial injury of shoulder } \\
\text { and upper arm; Disorders of } \\
\text { vestibular function) }\end{array}$ & & \\
\hline Total & 268 & 100 \\
\hline
\end{tabular}

Tables II and III showed data on antihypertension and antidiabetic use. All hypertension with comorbid T2DM patients uses antihypertension and antidiabetic drugs by the oral route of administration, either single or in combination. In addition, hypertension with comorbid
T2DM patients with other comorbidities also receives medication according to the patient's diagnosis.

Table II. Data of antihypertension used in patients with comorbid T2DM at Primary Health Care Center at Batununggal District Bandung

\begin{tabular}{lccc}
\hline Drug Name & $\begin{array}{c}\text { Routes of Drug } \\
\text { Administration }\end{array}$ & $\begin{array}{c}\text { Number } \\
\text { of } \\
\text { Patients }\end{array}$ & $\begin{array}{c}\text { Percentage } \\
\mathbf{( \% )}\end{array}$ \\
\hline $\begin{array}{l}\text { Amlodipine } \\
\text { Amlodipine } \\
+ \text { Captopril }\end{array}$ & Oral & 264 & 98.51 \\
\hline Total & Oral & 4 & 1.49 \\
\hline
\end{tabular}

Table III. Data of antidiabetic used in patients with comorbid T2DM at Primary Health Care Center at Batununggal District Bandung

\begin{tabular}{lccc}
\hline Drug Name & $\begin{array}{c}\text { Routes of Drug } \\
\text { Administration }\end{array}$ & $\begin{array}{c}\text { Number } \\
\text { of } \\
\text { Patients }\end{array}$ & $\begin{array}{c}\text { Percentage } \\
\mathbf{( \% )}\end{array}$ \\
\hline Metformin & Oral & 240 & 89.55 \\
Glimepiride & Oral & 1 & 0.37 \\
Metformin + & Oral & 18 & 6.72 \\
Glimepiride & Oral & 9 & 3.36 \\
$\begin{array}{l}\text { Metformin + } \\
\text { Glibenclamide }\end{array}$ & & & \\
\hline Total & & 268 & 100 \\
\hline
\end{tabular}

Table IV showed data of drug uses based on drug class. Besides antihypertension and antidiabetic drugs that were often used, from 268 patients, there was 170 use of vitamins: B1, B6, B12, or B complex. Vitamin B complex, B12, and B1 were widely used as supporting vitamins in reducing blood pressure and cholesterol levels. Vitamin B12 is prescribed to reduce complaints of aches suffered by patients and meet vitamin intake to avoid vitamin $B 12$ deficiency $^{16}$. Vitamin B12 deficiency can increase homocysteine levels, where high homocysteine levels can increase the risk of increased blood pressure through decreased availability of nitric oxide, thereby interfering with vascular vasodilation. Hyperhomocysteinemia can also damage the endothelium and cause atherosclerosis; therefore, vitamin $\mathrm{B} 12$ needs to be added ${ }^{17,18}$.

In hypertension with comorbid T2DM patients, pharmacists can also provide advice on nonpharmacological therapies such as lifestyle modification. Besides lowering blood pressure in patients with hypertension, lifestyle modification can also reduce blood pressure progression to hypertension in patients 
with prehypertension blood pressure ${ }^{19}$. A vital lifestyle modification that appears to lower blood pressure is weight loss for obese or obese individuals; adopt the DASH (Dietary Approach to Stop Hypertension) diet rich in potassium and calcium; low sodium diet; physical activity; and consume only a little alcohol. In several patients with reasonable blood pressure control with single antihypertensive drug therapy, reducing salt and weight can relieve patients from using the drugs ${ }^{20}$. Lifestyle modification alone is an appropriate therapy for patients with prehypertension. Patients diagnosed with stage 1 or 2 hypertension should be placed on concurrent lifestyle modification and drug therapy ${ }^{21}$.

Table IV. Data of drug used based on drug class in patients with comorbid T2DM at Primary Health Care Center at Batununggal District Bandung

\begin{tabular}{lccc}
\hline \multicolumn{1}{c}{ Drug Class } & $\begin{array}{c}\text { Routes of Drug } \\
\text { Administration }\end{array}$ & $\begin{array}{c}\text { Number } \\
\text { of } \\
\text { Patients }\end{array}$ & $\begin{array}{c}\text { Percentage } \\
\mathbf{( \% )}\end{array}$ \\
\hline Antidiabetic & Oral & 295 & 27.16 \\
Antihypertension & Oral & 272 & 25.05 \\
Vitamin & Oral & 170 & 15.65 \\
Antihyperlipidemia & Oral & 79 & 7.27 \\
Analgesics & Oral & 68 & 6.26 \\
Antipyretic & & & \\
NSAID & Oral & 34 & 3.13 \\
Antihistamine & Oral & 30 & 2.76 \\
Antihyperuricemia & Oral & 24 & 2.21 \\
Cough medicine & Oral & 23 & 2.12 \\
Calcium Lactate & Oral & 23 & 2.12 \\
Antacids & Oral & 17 & 1.57 \\
H2 Receptor & Oral & 7 & 0.64 \\
Antagonist & & & \\
Proton Pump & Oral & 7 & 0.64 \\
Inhibitor & & & \\
Antibiotics & Oral & 5 & 0.46 \\
Potent Diuretic & Oral & 4 & 0.37 \\
Antivertigo & Oral & 4 & 0.37 \\
Antidiarrheal & Oral & 4 & 0.37 \\
Antiemesis & Oral & 3 & 0.28 \\
Laksative & Oral & 1 & 0.09 \\
Antifungi & Topical & 6 & 0.55 \\
Corticosteroids & Topical & 3 & 0.28 \\
Antibiotics & Topical & 3 & 0.28 \\
Antibiotics & Ocular & 4 & 0.37 \\
\hline Total Usage & & 1086 & 100 \\
\hline & & & \\
\hline
\end{tabular}

Figure 1 shows the percentage of drug-related problems cases in patients with comorbid T2DM at Primary Health Care Center at Batununggal District Bandung. Problems related to the drugs analyzed were improper drug selection, overdose, subdose, and drug interactions. There are no cases of improper drug selection because patients received drugs according to therapy guidelines and drugs available at Primary Health Care Center at Batununggal District Bandung. There are also no cases of subdose. Based on the analysis results, it was found that 1 case $(0.37 \%)$ out of 268 patients experienced problems related to drug overdose, in which the patient received amlodipine $15 \mathrm{mg} /$ day. The maximum dose of amlodipine is $10 \mathrm{mg} /$ day $^{2}$.

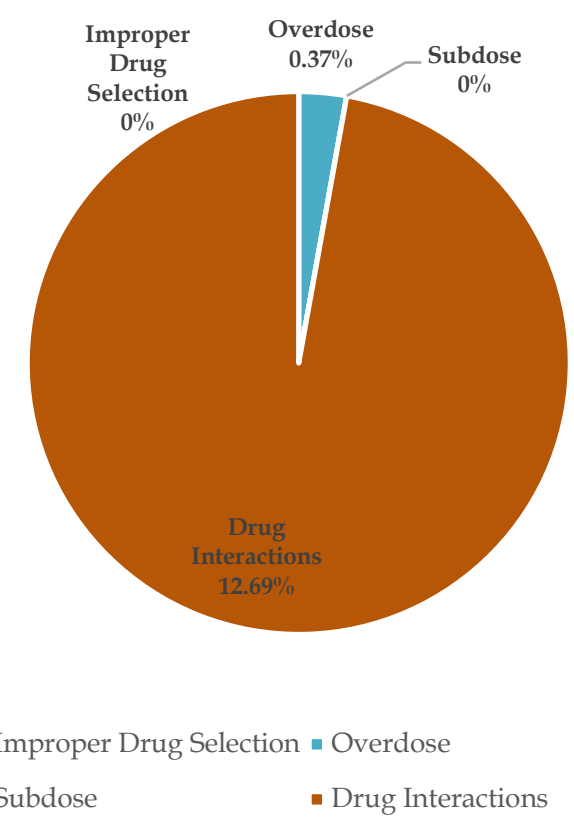

Figure 1. Percentage of drug-related problems cases in patients with comorbid T2DM at Primary Health Care Center at Batununggal District Bandung

In addition to overdoses, a potential drug-related problem is drug interactions. Figure $\mathbf{1}$ showed that 34 cases $(12.69 \%)$ out of 268 patients have potential drug interactions. Based on the analysis results in Table V, there was an interaction between amlodipine and nonsteroidal anti-inflammatory drugs like diclofenac sodium and mefenamic acid. Non-steroidal anti-inflammatory drugs can increase blood pressure and reduce the hypotensive effect of antihypertension ${ }^{23,24}$. These results can be considered so that the drug administration service to patients also provides suggestions for monitoring blood pressure. Home blood pressure monitoring (HBPM) is a self-monitoring tool recommended for patients with hypertension ${ }^{25}$. 
Table V. Potential drug interactions in patients with comorbid T2DM at Primary Health Care Center at Batununggal District Bandung

\begin{tabular}{llcc}
\hline $\begin{array}{c}\text { Drug } \\
\text { Interactions }\end{array}$ & $\begin{array}{l}\text { Effects of Drug } \\
\text { Interactions }\end{array}$ & $\begin{array}{c}\text { Treatment of } \\
\text { Drug } \\
\text { Interactions }\end{array}$ & $\begin{array}{c}\text { Number } \\
\text { of } \\
\text { Patients }\end{array}$ \\
\hline $\begin{array}{l}\text { Amlodipine } \\
+ \text { Sodium } \\
\text { Diclofenac }\end{array}$ & $\begin{array}{l}\text { NSAIDs can } \\
\text { increase blood } \\
\text { pressure and } \\
\text { reduce the } \\
\text { hypotensive } \\
\text { effect of } \\
\text { antihypertension }\end{array}$ & $\begin{array}{c}\text { Blood } \\
\text { pressure } \\
\text { monitoring }\end{array}$ & 16 \\
Amlodipine & $\begin{array}{l}\text { NSAIDs can } \\
\text { increase blood } \\
\text { pressure and } \\
\text { Mefenamic }\end{array}$ & $\begin{array}{c}\text { Blood } \\
\text { pressure } \\
\text { monitoring }\end{array}$ & \\
& $\begin{array}{l}\text { hypotensive } \\
\text { effect of } \\
\text { antihypertension }\end{array}$ & & \\
& & & \\
\hline Total & & & \\
\hline
\end{tabular}

The results in this study show a slight variation compared to other similar studies conducted in other locations. Other research results showed that drugrelated problems with the highest prevalence in clinical practice were caused by drug or dose selection ${ }^{26}$. Another study in patients with hypertension showed that the most identified drug-related problem was drug interactions ${ }^{27}$. At the same time, other research showed that the most common drug-related problems that occurred in T2DM with hypertension were insufficient awareness of health and diseases (26\%), drug choice problems $(23 \%)$, dosing problems $(16 \%)$, and drug interactions $(16 \%)^{28}$. Differences in research locations are important factors related to the types of drug-related problems encountered, especially for hypertensive patients with comorbid T2DM.

\section{CONCLUSION}

In the January-December 2019 period at Primary Health Care Center Batununggal District Bandung, drug-related problems on hypertension with comorbid T2DM patients were overdose and potential drug interactions. The pharmacist's role is needed in identifying drugrelated problems and being able to communicate these problems with other health professionals. It is recommended to carry out further research at the same health center or other health centers in order to obtain a more comprehensive conclusion.

\section{ACKNOWLEDGMENT}

We are grateful to the Institute for Research and Community Service (LPPM) of Universitas Jenderal Achmad Yani (UNJANI); therefore, this research can be carried out well.

\section{AUTHORS' CONTRIBUTION}

Vina Septiani: conceptualization, formal analysis, writing-original draft. Pudjiastuti Kartidjo: writingreview \& editing. Alfi Nurul Islamiyah: data curation.

Abdul Aziz M.S.W.: project administration. lis Rukmawati: resources.

\section{DATA AVAILABILITY}

None.

\section{CONFLICT OF INTEREST}

The authors declare no conflict of interest.

\section{REFERENCES}

1. Petrie JR, Guzik TJ, Touyz RM. Diabetes, Hypertension, and Cardiovascular Disease: Clinical Insights and Vascular Mechanisms. Can J Cardiol. 2018;34(5):575-84. doi:10.1016/j.cjca.2017.12.005

2. Akalu Y, Belsti Y. Hypertension and Its Associated Factors Among Type 2 Diabetes Mellitus Patients at Debre Tabor General Hospital, Northwest Ethiopia. Diabetes Metab Syndr Obes. 2020;13:1621-31. doi:10.2147/DMSO.S254537

3. Ohishi M. Hypertension with diabetes mellitus: physiology and pathology. Hypertens Res. 2018;41(6):389-93. doi:10.1038/s41440-018-0034-4

4. Einarson TR, Acs A, Ludwig C, Panton UH. Prevalence of cardiovascular disease in type 2 diabetes: a systematic literature review of scientific 
evidence from across the world in 2007-2017. Cardiovasc Diabetol. 2018;17:83. doi:10.1186/s12933018-0728-6

5. Guerrero-García C, Rubio-Guerra AF. Combination therapy in the treatment of hypertension. Drugs Context. 2018;7:212531. doi:10.7573/dic.212531

6. Al-Azzam SI, Alzoubi KH, AbuRuz S, Alefan Q. Drug-related problems in a sample of outpatients with chronic diseases: a cross-sectional study from Jordan. Ther Clin Risk Manag. 2016;12:233-9. doi:10.2147/tcrm.s98165

7. Anshila MK, Nambiar DP, Augustine DV, Saseendran M, Shabraya AR, Siva S. Evaluation of Drug Related Problems in Patients with Chronic Disease at Tertiary Care Teaching Hospital. Int J Health Sci Res. 2020;10(9):144-55.

8. Septiani V, Sutjiatmo AB, Rustam LD. Identification of Drug-Related Problems (DRPs) Antihypertension on Hypertension Patient with Hyperlipidemia at One of Puskesmas in Bandung. In Asian Federation for Pharmaceutical Sciences (AFPS) 2019. Depok: Universitas Indonesia.

9. DiPiro JT, Yee GC, Posey M, Haines ST, Nolin TD, Ellingrod V. Pharmacotherapy: A Pathophysiologic Approach. 11 th ed. New York: McGraw Hill Professional; 2020.

10. Ministry of Health Republic of Indonesia. Hasil Utama Riskesdas 2018. Jakarta: Health Research and Development Agency, Ministry of Health Republic of Indonesia; 2018.

11. Sabbatini AR, Kararigas G. Estrogen-related mechanisms in sex differences of hypertension and target organ damage. Biol Sec Differ. 2020;11:31. doi:10.1186/s13293-020-00306-7

12. Singh S, Shankar R, Singh GP. Prevalence and Associated Risk Factors of Hypertension: A CrossSectional Study in Urban Varanasi. Int J Hypertens. 2017;2017:5491838. doi:10.1155/2017/5491838

13. Nishiwaki M, Yonemura H, Kurobe K, Matsumoto $\mathrm{N}$. Four weeks of regular static stretching reduces arterial stiffness in middle-aged men. Springerplus. 2015;4:555. doi:10.1186/s40064-015-1337-4

14. Qiu L, Wang W, Sa R, Liu F. Prevalence and Risk Factors of Hypertension, Diabetes, and Dyslipidemia among Adults in Northwest China. 2021;2021:5528007. doi:10.1155/2021/5528007
15. Yimama M, Jarso H, Desse TA. Determinants of drug-related problems among ambulatory type 2 diabetes patients with hypertension comorbidity in Southwest Ethiopia: a prospective cross sectional study. BMC Res Notes. 2018;11:679. doi:10.1186/s13104-018-3785-8

16. Tardy AL, Pouteau E, Marquez D, Yilmaz C, Scholey A. Vitamins and Minerals for Energy, Fatigue and Cognition: A Narrative Review of the Biochemical and Clinical Evidence. Nutrients. 2020;12(1):228. doi:10.3390/nu12010228

17. Moretti R, Caruso P. The Controversial Role of Homocysteine in Neurology: From Labs to Clinical Practice. Int J Mol Sci. 2019;20(1):231. doi:10.3390/ijms20010231

18. Tinelli C, Di Pino A, Ficulle E, Marcelli S, Feligioni M. Hyperhomocysteinemia as a Risk Factor and Potential Nutraceutical Target for Certain Pathologies. Front Nutr. 2019;6:49. doi:10.3389/fnut.2019.00049

19. Fu J, Liu Y, Zhang L, Zhou L, Li D, Quan H, et al. Nonpharmacologic Interventions for Reducing Blood Pressure in Adults with Prehypertension to Established Hypertension. J Am Heart Assoc. 2020;9(19):e016804. doi:10.1161/jaha.120.016804

20. Carey RM, Muntner P, Bosworth HB, Whelton PK. Prevention and Control of Hypertension: JACC Health Promotion Series. J Am Coll Cardiol. 2018;72(11):1278-93. doi:10.1016/j.jacc.2018.07.008

21. Mahmood S, Shah KU, Khan TM, Nawaz S, Rashid $\mathrm{H}$, Baqar SWA, et al. Non-pharmacological management of hypertension: in the light of current research. Ir J Med Sci. 2019;188(2):437-52. doi:10.1007/s11845-018-1889-8

22. Fares H, DiNicolantonio JJ, O'Keefe JH, Lavie CJ. Amlodipine in hypertension: a first-line agent with efficacy for improving blood pressure and patient outcomes. Open Heart. 2016;3(2):e000473. doi:10.1136/openhrt-2016-000473

23. Wongrakpanich S, Wongrakpanich A, Melhado K, Rangaswami J. A Comprehensive Review of NonSteroidal Anti-Inflammatory Drug Use in The Elderly. Aging Dis. 2018;9(1):143-50. doi:10.14336/AD.2017.0306

24. Baxter, K. Stockley's Drug Interactions. $8^{\text {th }}$ ed. London: Pharmaceutical Press; 2008. p. 861-863. 
25. George J, MacDonald T. Home Blood Pressure Monitoring. Eur Cardiol. 2015;10(2):95-101. doi:10.15420/ecr.2015.10.2.95

26. Garin N, Sole N, Lucas B, Matas L, Moras D, RodrigoTroyano A, et al. Drug related problems in clinical practice: a cross-sectional study on their prevalence, risk factors and associated pharmaceutical interventions. Sci Rep. 2021;11:883. doi:10.1038/s41598-020-80560-2

27. Farha RA, Saleh A, Aburuz S. The impact of drug related problems on health-related quality of life among hypertensive patients in Jordan. Pharm Pract. 2017;15(3):995. doi:10.18549/PharmPract.2017.03.995

28. Huri ZH, Wee HF. Drug related problems in type 2 diabetes patients with hypertension: a cross-sectional retrospective study. BMC Endocr Disord. 2013;13:2. doi:10.1186/1472-6823-13-2 